\title{
Design and Implementation of a Hospital Database Management System (HDMS) for Medical Doctors
}

\author{
Amaechi James C., Agbasonu Valerian C., and Nwawudu Sixtus E.
}

\begin{abstract}
This paper aimed at designing and implementing an automated system that will alleviate the problem of handling patients' data in a hospital. The researchers were motivated to embark on this project because of the inherent problems of the manual system of hospitals file management. This manual system has so many problems associated with it such as insecurity of files, poor file retrieval system and inefficient file update system etc. This paper examines an existing information system of a hospital and designed an automated system that can help Medical Doctors and those who handle hospitals' data to perform their work more effectively and efficiently. The System would be developed with a Window, Apache, MySQL and PHP (WAMP) software. The HDBMS would be a web application that runs in a computer network. It would provide easy and fast access to stored data as needed by different users with security against unauthorized access. Any authorized user can add, delete and update data into the database base on their user-assigned-role. It would equally have the facility to give a unique identity for every persons and stores the details of every patient and the staff automatically. It includes a search facility to know the current status of each room in the hospital. A user can search availability of doctors and the details of a patient using the system. The interface is very user-friendly.
\end{abstract}

Index Terms-Hospitals, database, management, medical doctors, patients, system.

\section{INTRODUCTION}

Hospitals are key institutions and there is need for efficient service delivery in the hospital as good health is paramount to a happy society. As a result of this there is need for a system that will enable hospital management in making effective and efficient decision [1]. Recently, efforts are continuously being made in designing and constructing a user friendly and reliable database system to satisfy hospital or medical management system [2], [3].

On the other hand, many hospitals and medical centers are still adopting the manual system of hospital management. These methods of medical management system have continued to pose a lot of setbacks and problems to medical practitioners, nurses, patients and other staff in both government and private hospitals.

\footnotetext{
Manuscript received November 25, 2017; revised January 23, 2018. Amaechi James C. is with the Widow and Orphans Empowerment, 110 Pent City Estate, Lokogoma Abuja, Nigeria (e-mail: berogu12@gmail.com).

Agbasonu Valerian C. is with IMO State University, Nigeria (e-mail: valpraise@gmil.com).

Nwawudu Sixtus E. is with NESN Humanitarian and Research Initiative 31 rue Berthelot 4210 Saint-Etienne, France (e-mail: ezenwawudu@yahoo.com).
}

\section{A. The Need for Database Management Systems in Hospital}

All large enterprises need the database systems for handling the information [2]. One kind of those enterprises is the hospital. Because of large number of patients, doctors and other staff in hospitals, data processing becomes more crucial. Data Management in hospital can be used for achieving the patient's information, arranging the doctors schedule and accounting business. Doctors should access the patient's record for giving the best diagnosis to cure the patient [4].

On the other hand patient can access their lab results and all kinds of information that doctors indicate. Data base hospital helps to control the accounting business easily.

\section{B. Functions Provided in the Hospital Database Management System}

In the database management system all information including prescription, survey, and diagnosis of patients can be carried out [2].

1) All information includes prescription survey, diagnosis of patients.

2) The patients and the doctor can handle all information

3) Patients can take appointment time for visiting and can access their information via interest if the organization is online.

4) Administration can access the statistics about the hospital such as patients capacity, number of employee etc.

\section{SOURCES OF DATA}

\section{A. Observation Method}

The researcher made several visits to the hospitals to observe and analyses the mode of operation for the management.

\section{B. Interview}

The doctors and some of the personnel were interviewed in order to acquire some facts that will help in building the new system.

\section{Information from Published Sources}

Pieces of information were gathered from many existing publication on this subject. Several books and journals on hospital database management were consulted to get information that would be necessary for the designs of the new system.

\section{Documentation and Events in the Hospitals}

Many hospitals are still adopting the manual system of 
hospital management. This method of hospital management have continued to pose a lot of setbacks, and problems to medical practitioners, nurses, patients and other staffs both private and government hospitals.

Thus, a good example of these hospitals that are yet to adopt the automated system of hospital management is Our Lady of Mercy Hospital in Owerri. A case day shows that Mercy hospital has over two thousand patient in a week most of whom are out patient and they treat between $30-50$ patients per day.

\section{E. Organizational Structure of the Hospital}

The diagram in Fig. 1 shown below illustrates the hierarchy structure of Our Lady of Mercy hospital.

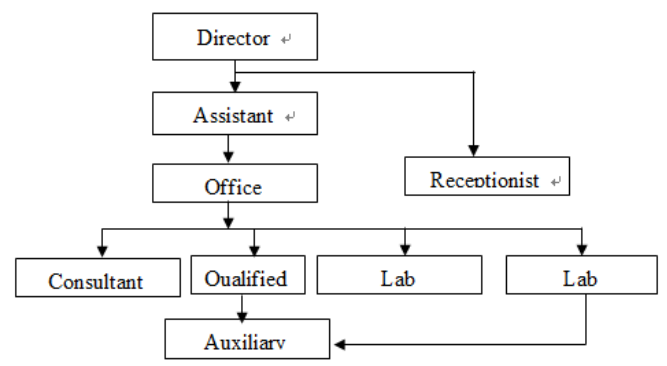

Fig. 1. Organizational structure of the hospital.

As seen from the chart in Fig. 1, the hospital is made up of the following personnel:

1) Director (medical doctor).

2) Assistant (medical doctor).

3) Office manager.

4) The consultant medical doctors.

5) Eight qualified nurses, two auxiliary nurses.

6) The receptionist.

7) The laboratory technologists etc.

\section{METHODS OF KEEPING RECORDS}

The hospital accumulates the files and records of patients, stock and payroll and processes them after the space of one month.

\section{A. Input and Output System}

The system constitutes of patients inventory which would contain patients records arrangement or organized in file and the general stores record which includes the input of the quantity in stock the drug code, drug number and the expiring date of each drug in database.

The output to generate from this system will be to update, add, delete, clear, and provide summary of the total monthly, yearly even daily records of events in the various departments of the hospital. It will also produce the estimate of report generated by very given module.

\section{B. Files and Records}

The files and records will both contain the detail of the event carried out in every department as performed by each particular module or form.

\section{Problems and Weakness of the Current System}

The problem observed in the current system has to do with cost. The startup costs are enormous. Not only must you buy equipment to record and store patient charts (much more expensive than paper and file cabinets), but efforts must be taken to convert all charts to electronic form Patients may be in the transitional state, where old records haven't yet been converted and doctors don't always know this. Further, training on the hospital software adds additional expense in paying people to take training, and in paying trainers to teach practitioners.

Also, some are concerned about the security of their medical records, which should be completely confidential. Hackers may ultimately be able to penetrate the system despite security precautions, and they may then release confidential information to others. This has some patients worried about how safe and confidential their electronic medical records really are.

\section{System Proposal/Proposal of NEW System}

The proposed system is going to focus on the personnel and patients management system. The proposed system is also aimed at achieving computer management base system. See the flow chart of the proposed new system in Fig. 2.

\section{A. Expectation of the New System}

1) To fully automate the operation of the hospital and managerial system in the hospital.

2) To improve and standardize practice planning of efficient and communication skill in the hospital.

3) To achieve good computing skills for the management and staff of the hospital.

4) To improve the accurate record keeping in the hospital

5) To provide timely access to patients and personnel records.

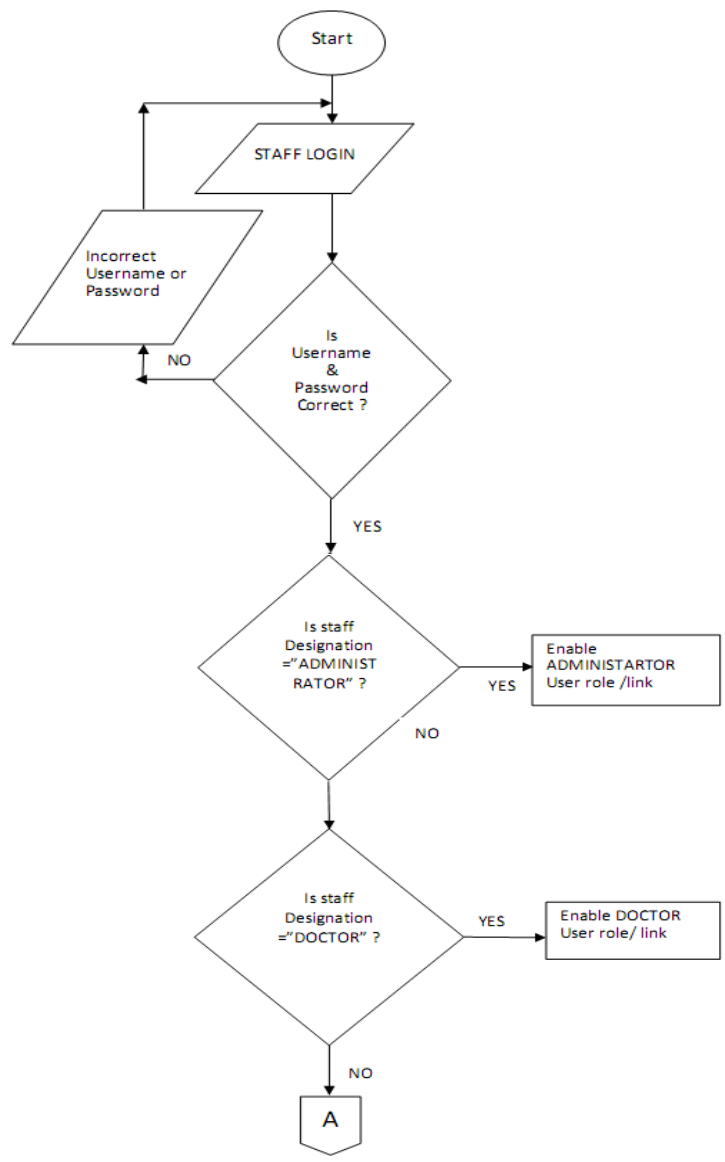




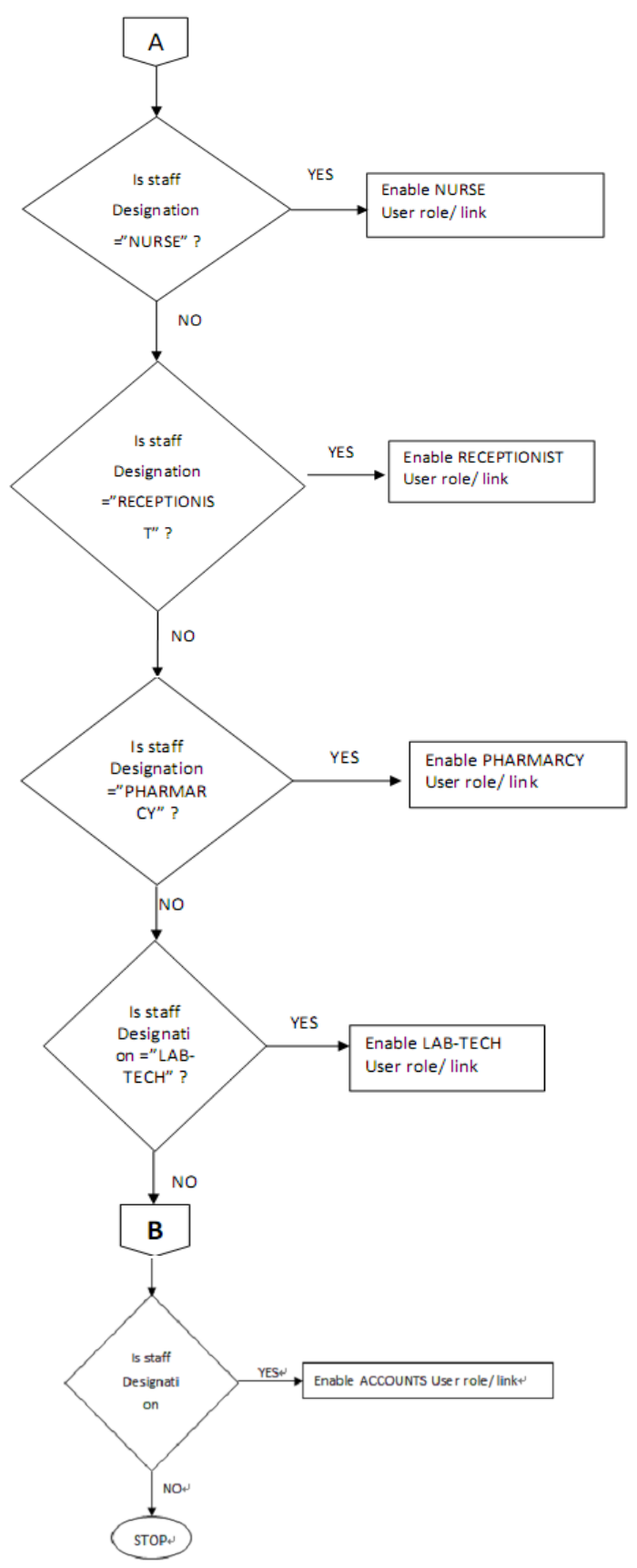

Fig. 2. New system.

\section{B. Justification of the New System}

This system is justified based on the cost of running the manual system compared with the one of the automated system.

From observation and interview through case study, we found out that the management spent much money on buying files and folders stores for alter access, hence from analysis, the hospital spent up to forty thousand Naira ( $\$ 40,000.00$ ) on buying files and stationary every month.

While the installation and running of this new system will cost at most $¥ 400,000.00$ hence it is considered more advantageous for the management.

\section{Advantages of the New System}

The following are the out timed advantages of proposed system:

1) It offers the hospital on management issues and provides a base for large database.
2) It offers the hospital accurate information on management issues and provides bases for large database.

3) It also exposes the user to the knowledge of computing. The system put a stop to unnecessary waste of time in carrying out operations in the hospital.

\section{System Design}

The objective is to fully automate the operation and management of Our Lady of Mercy Medical centre, Owerri. The scope of the system is to develop a database system that automates all the activities of patients in the hospital starting from their registration to their discharge from the hospital. The system to be developed would have the following modules as seen from the case study [5].

1) The Administrative module

2) The Receptionist module

3) The Medical Doctor Module

4) The pharmacy Module

5) The Nurse Module

6) The Lab-Technologist module

7) The Account module

\section{PROGRAM STRUCTURE}

The Hospital database application runs in a web browser. It was specially customized for Mozilla Firefox and Safari browsers. It welcomes user to the introductory screen of the package with the following information.

1) The logo and banner of Our Lady of Mercy Hospital,

2) Login section at the left hand side, which is requesting for the username and password of the user in other to use the application,

3) Slides of pictures displaying various section and equipment of the hospital at the centre of the application,

4) And a summary information of the applicability of the Hospital application.

Username and password are necessary for one to use the application. If you click on login without providing the password, it will alert you to provide the password. Then if you provide wrong username or password, it will inform you accordingly without opening the system for you. It is designed to make use of e-mail addresses for username field.

If you have a successful login process, the application will enable a hyperlink that assign duties base on user role. For instance the user role of a Nurse is different from that of a Doctor. A Doctor can prescribe a Drug to the patients whereas a Nurse cannot.

\section{A. System Requirement}

The system requirement includes the software and the hardware that make the package being developed to run effectively. It also requires networking devices that will enable connection within a Local Area Network (LAN).

\section{B. Software Requirement}

The software requirements are basically for both the server and clients. The server side requires Window Apache MySQL PHP (WAMP), whereas the clients require only the web browsers. The following are the list: 
1) WAMP server

2) Web Browser (Mozilla Firefox or Safari)

3) Operating system (Windows XP, Windows 7)

\section{Hardware Requirement}

This affects the usability and functionality of database on the hospital management system. The software runs on a standard hardware whether in time sharing network, mainframe or minicomputers, thus the hardware requirements are: IBM Intel or Microsoft compatible computers. A hard disk capacity of at least $2 \mathrm{~GB}$, random access Memory (RAM) size at least 64MB. Pentium II of speed at least $26 \mathrm{~Hz}$, Laser Jet/Desk jet Printer, CD/DVD writers, CD ROMs for backing up files or DVD ROMs, A switch that connects all the client computers to the server, and network cables that connect all the hospital units to the server.

\section{System Input/Output Design}

The input design for the patients record in the data entry design shown in Table I, II, III and IV.

\begin{tabular}{|c|c|c|c|c|}
\hline $\mathbf{S} / \mathbf{N}$ & Fields & $\begin{array}{l}\text { Data Type } \\
\text { (Field width) }\end{array}$ & $\begin{array}{l}\text { Relatio } \\
\text { nships }\end{array}$ & Description \\
\hline 1 & patients_id & Varchar(20) & $\begin{array}{l}\text { Primar } \\
\text { y Key }\end{array}$ & $\begin{array}{l}\text { Patient } \\
\text { Identifier/Car }\end{array}$ \\
\hline 2 & patients_firstname & Varchar(30) & $\begin{array}{l}\text { Not } \\
\text { Null }\end{array}$ & $\begin{array}{l}\text { Patients } \\
\text { firstname }\end{array}$ \\
\hline 3 & patients_lastname & Varchar(30) & $\begin{array}{l}\text { Not } \\
\text { Null }\end{array}$ & $\begin{array}{l}\text { Patients } \\
\text { lastname }\end{array}$ \\
\hline 4 & Age & Int & $\begin{array}{l}\text { Not } \\
\text { Null }\end{array}$ & Patients age \\
\hline 5 & marital_status & Varchar(10) & $\begin{array}{l}\text { Not } \\
\text { null }\end{array}$ & $\begin{array}{l}\text { Patients } \\
\text { marital status }\end{array}$ \\
\hline 6 & Gender & Varchar(10) & $\begin{array}{l}\text { Not } \\
\text { null }\end{array}$ & $\begin{array}{l}\text { Patients } \\
\text { gender }\end{array}$ \\
\hline 7 & Lga & Varchar(30) & $\begin{array}{l}\text { Not } \\
\text { Null }\end{array}$ & $\begin{array}{l}\text { Patients LGA } \\
\text { origin }\end{array}$ \\
\hline 8 & State & Varchar(20) & $\begin{array}{l}\text { Not } \\
\text { Null }\end{array}$ & $\begin{array}{l}\text { Patients state } \\
\text { of origin }\end{array}$ \\
\hline 9 & home_address & Varchar(100) & $\begin{array}{l}\text { Not } \\
\text { Null }\end{array}$ & $\begin{array}{l}\text { Patients home } \\
\text { address }\end{array}$ \\
\hline 10 & resident_address & Varchar(100) & $\begin{array}{l}\text { Not } \\
\text { Null }\end{array}$ & $\begin{array}{l}\text { Patient } \\
\text { resident } \\
\text { Address }\end{array}$ \\
\hline 11 & phone_no & Varchar(15) & $\begin{array}{l}\text { Not } \\
\text { Null }\end{array}$ & $\begin{array}{l}\text { Patients } \\
\text { Phone number }\end{array}$ \\
\hline 12 & Email & Varchar(30) & $\begin{array}{l}\text { Not } \\
\text { Null }\end{array}$ & $\begin{array}{l}\text { Patients E- } \\
\text { mail }\end{array}$ \\
\hline 13 & next_of_kin_id & Varchar(5) & $\begin{array}{l}\text { Foreign } \\
\text { key }\end{array}$ & $\begin{array}{l}\text { Next of kin } \\
\text { Identity }\end{array}$ \\
\hline 14 & Comment & Varchar(200) & $\begin{array}{l}\text { Not } \\
\text { Null }\end{array}$ & $\begin{array}{l}\text { Receptionist } \\
\text { comment }\end{array}$ \\
\hline 15 & $\begin{array}{l}\text { Symptom_ } \\
\text { sickness }\end{array}$ & Varchar(200) & $\begin{array}{l}\text { Not } \\
\text { Null }\end{array}$ & $\begin{array}{l}\text { Patients } \\
\text { sickness }\end{array}$ \\
\hline 16 & Passport & Varchar(20) & $\begin{array}{l}\text { Not } \\
\text { Null }\end{array}$ & $\begin{array}{l}\text { Patient } \\
\text { Passport }\end{array}$ \\
\hline 16 & Patint_type & Varchar(20) & Not & In/Out Patient \\
\hline
\end{tabular}

\begin{tabular}{|l|l|l|l|l|}
\hline 17 & Passport & Varchar(20) & $\begin{array}{l}\text { Not } \\
\text { Null }\end{array}$ & $\begin{array}{l}\text { Patient } \\
\text { Passport }\end{array}$ \\
\hline 18 & time_of_reg & Varchar(20) & $\begin{array}{l}\text { Not } \\
\text { Null }\end{array}$ & $\begin{array}{l}\text { Time of } \\
\text { Registration }\end{array}$ \\
\hline 19 & Admin & Varchar(30) & Not & $\begin{array}{l}\text { The staff that } \\
\text { registered } \\
\text { patient }\end{array}$ \\
\hline
\end{tabular}

TABLE II: PATIENTS TRIAGE

\begin{tabular}{|c|c|c|c|c|}
\hline $\mathbf{S} / \mathbf{N}$ & Fields & $\begin{array}{l}\text { Data Type } \\
\text { (Field width) }\end{array}$ & $\begin{array}{l}\text { Relations } \\
\text { hips }\end{array}$ & Description \\
\hline 1 & triage_id & Varchar(5) & $\begin{array}{l}\text { Primary } \\
\text { Key }\end{array}$ & $\begin{array}{l}\text { Each Triage } \\
\text { identity }\end{array}$ \\
\hline 2 & patients_id & Varchar(5) & $\begin{array}{l}\text { foreign } \\
\text { Key }\end{array}$ & $\begin{array}{l}\text { Patients } \\
\text { identity }\end{array}$ \\
\hline 3 & nurse_id & Varchar(5) & $\begin{array}{l}\text { foreign } \\
\text { Key }\end{array}$ & Nurse identity \\
\hline 4 & blood_pressure & Varchar(20) & Not Null & Blood Pressure \\
\hline 5 & heart_beat & Int & Not Null & Heart beat \\
\hline 6 & sugar_level & Varchar(20) & Not Null & $\begin{array}{l}\text { Patients sugar } \\
\text { level }\end{array}$ \\
\hline 7 & Height & Varchar(20) & Not Null & Patients height \\
\hline 8 & Weight & Varchar(20) & Not Null & $\begin{array}{l}\text { Patients } \\
\text { weight }\end{array}$ \\
\hline 9 & time_of_reg & Varchar(20) & Not Null & $\begin{array}{l}\text { Time of triage } \\
\text { check }\end{array}$ \\
\hline 10 & Comment & Varchar(200) & Not Null & $\begin{array}{l}\text { Nurse } \\
\text { comment }\end{array}$ \\
\hline 11 & Fee & Int & $\begin{array}{l}\text { Primary } \\
\text { Key }\end{array}$ & Fee charge \\
\hline
\end{tabular}

TABLE III: PATIENT TEST

\begin{tabular}{|c|c|c|c|c|}
\hline $\begin{array}{l}\mathbf{S} / \\
\mathbf{N}\end{array}$ & Fields & $\begin{array}{l}\text { Data Type } \\
\text { (Field width) }\end{array}$ & $\begin{array}{l}\text { Relatio } \\
\text { nships }\end{array}$ & Description \\
\hline 1 & test_id & Varchar(5) & $\begin{array}{l}\text { Primary } \\
\text { Key }\end{array}$ & $\begin{array}{l}\text { Each Test } \\
\text { identity }\end{array}$ \\
\hline 2 & test_name & Varchar(20) & $\begin{array}{l}\text { Not } \\
\text { Null }\end{array}$ & Test name \\
\hline 3 & test_description & Varchar(50) & Null & Test description \\
\hline 4 & patients_id & Varchar(5) & $\begin{array}{l}\text { Foreign } \\
\text { key }\end{array}$ & Patients identity \\
\hline 5 & lab_scientist_id & Varchar(5) & $\begin{array}{l}\text { Foreign } \\
\text { key }\end{array}$ & $\begin{array}{l}\text { Lab technologist } \\
\text { identity }\end{array}$ \\
\hline 6 & doctor_id & Varchar(5) & $\begin{array}{l}\text { Foreign } \\
\text { key }\end{array}$ & Doctors identity \\
\hline 7 & Date_time & Date/Time & $\begin{array}{l}\text { Not } \\
\text { Null }\end{array}$ & $\begin{array}{l}\text { Date and time of } \\
\text { test prescription }\end{array}$ \\
\hline 8 & return_date & Date/time & $\begin{array}{l}\text { Not } \\
\text { Null }\end{array}$ & Return date \\
\hline 9 & test_result & Varchar(50) & $\begin{array}{l}\text { Not } \\
\text { Null }\end{array}$ & Test result \\
\hline 10 & Comment & Varchar(200) & Null & $\begin{array}{l}\text { Lab scientist } \\
\text { comment }\end{array}$ \\
\hline 11 & Fee & Int & $\begin{array}{l}\text { Not } \\
\text { Null }\end{array}$ & Fee charge \\
\hline
\end{tabular}


TABLE VI: PATIENTS' BILL

\begin{tabular}{|l|l|l|l|l|}
\hline S/N & Fields & $\begin{array}{l}\text { Data Type } \\
\text { (Field width) }\end{array}$ & Relationships & Description \\
\hline 1 & bill_id & Varchar(50) & Primary Key & bill identity \\
\hline 2 & patients_id & Varchar(5) & Foreign Key & $\begin{array}{l}\text { Patients } \\
\text { identity }\end{array}$ \\
\hline 3 & doctor_charge & Int & Not Null & \\
\hline 4 & medicine_charge & Int & Not Null & \\
\hline 5 & room_charge & Int & Not Null & \\
\hline 6 & operation_charge & Int & Allow Null & \\
\hline 7 & no_of_days & Int & Allow Null & \\
\hline 8 & nursing_charge & Int & Allow Null & \\
\hline 9 & Advance & Int & Allow Null & \\
\hline 10 & health_card & Varchar(50) & Allow Null & \\
\hline 11 & lab_charge & Int & Allow Null & \\
\hline 12 & Bill & Int & Not Null & Total Fee \\
& & & & \\
\hline
\end{tabular}

\section{E. Database File Specification}

The files and records in the database are accessed by the following methods [3].

\section{1) Direct access}

The access of files in the database by the use of key field or index.

\section{2) Serial access}

This is accomplishing in a project with use of data control to move to the next previous first or last records in the database.

\section{F. The System Development}

The development of this hospital database management system was carried out following the procedures for developing a system using system development life circle (SDLC).

The system is already existing system of management in the hospital was identified, defined and followed by identifying the problems, setbacks and bottleneck of the existing system, hence the alternative solution to the problems, device and implementation to put the automated system in place, following the identification and definition of problems in our lady of mercy hospital. Feasibility study carried out to find facts will help in the modeling of the new computerized system. More so, the new system has been analyzed in terms of the problem and the setbacks facing it. Hence the development of the system emerged. Perhaps, the new system is also available for some operations like updating and modification of the programs in future, hence it is open for maintenance and well documented.

\section{PROGRAM DESIGN}

The program is designed as a web application that runs on web browsers, more especially Mozilla Firefox. The entire program development is a set of program module, each performing a specific task as shown in the general structure of the system [6].

The program involves user interface, thereby making the developed package user friendly. The options are accessible through popup menus at the hyperlink such as Doctor's popup menu where you get view patients, Diagnose patients, subscribe drugs etc. Popup menus will only display options base on your job description or user-role. The logout button is always there beside the welcome message to allow a user to logout after usage.

\section{A. Testing and Evaluation}

First and foremost, the skeleton of the entire system was set up with a module for the initialization phase. After testing to verify accuracy, subroutines were added. Thus, the systematic top down testing before the rest lager of complexity was added.

Hence, during implementation, programmers worked on modules in parallel and periodic testing and check performance of the whole system allowed management growth in complexity without introducing untraceable bugs. This involves the training of user in the operation of a new information system.

\section{B. System Change Over}

This process can be achieved in two ways:

1) Gradual system change over

2) Direct/immediate or direct systems change over

1) Gradual system change over

This happens when the new system, run alongside the manual or old system and after a period of time the old system is phased out and the new system continues.

2) Direct/immediate or direct systems change over

This involves changing over directly to the en system without any significant delay.

\section{System Maintenance}

Maintenance function begins once the system is fully implemented. This is the process of making modification after the software has been delivered. This requires an understanding of the program. This is achieved by clearly studying the program code and associated documentation. There are usually two types of maintenance. Enhancement maintenance has to do with the modification of the software due to changes in the ever dynamic environment and corrective maintenance is carried out as a result of error discovered after delivering the software.

\section{RECOMMENDATIONS}

Since data in the Medical Centre are so essential that the management cannot do without it, then we do suggest that the management of Our Lady of Mercy hospital should as much as possible ensure that:

1) There are backups for all files for security reasons. Each office has its own computer with a large memory to run the program.

2) Each of the offices should be networked in order to reduce the need to be moving files from one office to another and also to save time.

3) Uninterruptible power supply (UPS) with Inverter should be provided for every computer to reduce the 
rate for hard disk or system failures.

4) Adequate power generating means should be provided to meet up with demands.

\section{CONCLUSION}

The developed system and its evaluation so far have been carried out to improve the database system and management processes in Our Lady of Mercy hospital. Thus, care was taken to handle the way information about the hospital and patients were treated from the first.

Usually, as the population of an area increases and the database gets bigger. Hence, the Hospital database management needs to be improved or upgraded to meet any situation. It is capable of storing variety and large volume of database. More so, the software has been designed to include program modules to handle the Medical Centre information such as patients' data, supply (drug) management, patients bill etc.

Thus, this software contains the database files of hospital database file of Our Lady of Mercy Hospital and will provide the necessary information of the hospital and also will be compatible, accurate, flexible, secured and efficient for the desired purpose it is to serve.

\section{REFERENCES}

[1] C. C. Oparah, Genesis of Computer, Nigeria Pradses Books \& Press, 2006.

[2] J. I. Abdullahi, Introduction to Computer Management Tool, Nigeria Victory Publishers, 2004.

[3] E. H. James and J. J. Cimino, Biomedical Informatics: Computer Applications in Health Care and Biomedicine, 3rd ed. New York: Springer, 2006
[4] D. L. Kusis, The Medical Philosophy, Texas University of Medicine Texas, USA, 2002.

[5] C. S. French, Computer Science, 5th ed. 1996.

[6] C. O. ANI, Assembly Language Programming, Immaculate Publication L. T. D Enugu, 2002.

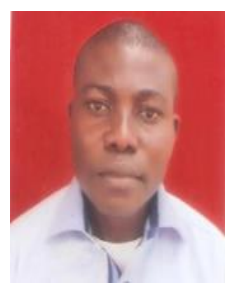

James C. Amaechi is a graduate of computer science from Anambra State University of Science and Technology, Uli, Anambra State, Nigeria. He currently works at Widows and Orphans Empowerment, Abuja, Nigeria.

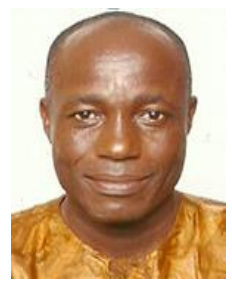

Agbasonu Valerian C. (Ambp) is a lecturer of the Department of Computer Science at Imo State University Owerri. $\mathrm{He}$ has the $\mathrm{PhD}$ in computer/information system from American Heritage University of Southern California USA; the $\mathrm{PhD}$ in computer science from the Imo State University Nigeria; the M.Sc. in computer science from the Ambrose Ali University, Ekpoma, Nigeria; the PGD in computer science from Federal University of Technology/CCE Owerri; the PGD Education and B.Sc. hons in statistics from University of Nigeria, Nuskka.

Dr. Agbasonu has authored and co-authored many textbooks and published many articles in reputable local and international journals. He is a member of many professional bodies like Computer Professionals of Nigeria (CPN), International Society of Telemedicine and eHealth (ISFTEH).

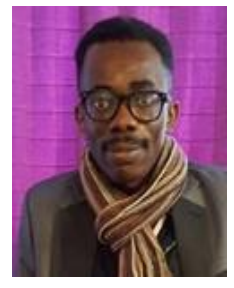

Nwawudu Sixtus Ezenwa was born in 1979. He has the B. Tech degree in computer science, diploma in French language, culture and civilisation from Université Jean Monnet, France, the M.Sc. in biometrics, optics, image, vision and multimedia from Université Paris-Est, Créteil (UPEC), France. His current research interests are image and signal, data mining, 3D visualization, bioinformatics, image and signal, e-medicine etc. 